\title{
Lucy Aikin and the legacies of Dissent
}

\section{Felicity James}

I want to begin with a snowy journey, a bitter cold long trek across country from a child's view point:

My grandmother, her maid, my little brother, and myself, were packed in a postchaise; my father accompanied us on horseback. It was Christmas week, the snow deep on the ground; the whole distance was two hundred and forty miles across the country, and we were six days in accomplishing it. ${ }^{1}$

This is the image with which Lucy Aikin begins her reminiscences, published by her nephewin-law Philip Hemery Le Breton in 1864. She was three years old when her father, John Aikin junior, left Warrington Academy for Yarmouth, and the long journey across country, from one Dissenting stronghold to another, took its toll upon the family. 'The last night we arrived at my aunt's, Mrs. Barbauld's, house at Palgrave,' she goes on, 'where my grandmother remained behind; she died in a few days of the cold and fatigue of the journey.' Yet in some ways this memorial of her grandmother turns out not to be an act of family piety - like the poetry written by Barbauld about her female ancestors - but an overdue redress, since the grandmother is primarily remembered not with fondness, but for having rebuked the infant Aikin:

My father's mother, who lived in the house with us, made some attempts to teach me to read; the extraordinary precocity of my aunt and of my eldest brother had perhaps rendered her unreasonable in her expectations of progress; she called me 'Little Dunce'; the reproach sank deep, and its effect was certainly unfavourable; it did not 
rouse me to further exertion, for I had already done my utmost, and it filled me with a sense of incurable deficiency. How soon may the tender spirit of a child be broken, and its faculties permanently dulled by such treatment $!^{2}$

Already we have a sense of family history as vexed, as members are unreasonably compared to one another. The formidable intellectual inheritance of the Aikin family is shown to be a burden, as well as a blessing. For the Aikins, as Michelle Levy and Daniel White have explored, 'the home is part of the public sphere, and the family itself is the institution most capable of effecting profound national change', and in this volume different essays have demonstrated the ways in which such a family ethos was gradually constructed across the generations. ${ }^{3}$ In Lucy Aikin's writing, however, we see the pressure of having inherited this collective identity, as she attempts to maintain and continue family legacies whilst also negotiating a place for her own role as a woman writer. Lucy Aikin's vivid recollection of the smart of a childhood insult bears a close similarity to the Autobiography of Harriet Martineau, another Unitarian daughter, who also reports in detail childhood injuries and injustices which demonstrate the problems of establishing an identity within the larger family narrative. For Martineau release came through the collapse of the family textile business, allowing her 'a wholly new freedom' to write and publish; she further distanced herself through her later rejection of Unitarianism. ${ }^{4}$ For Lucy Aikin, a junior partner in the family business of letters, independence was harder to achieve.

Although her work has endured a long period of neglect, Lucy Aikin was a successful author in the nineteenth century, and her writing - which ranged from poetry to fiction, writing for children, literary criticism and biography - is now once again attracting critical attention. As Michelle Levy discusses in detail elsewhere in this volume, it was for her work as a historian that Aikin was probably best known in her lifetime. She was, as Levy shows, an 
impressive and innovative historical writer; it is, however, her role as a family historian which I want to address in detail in this chapter. In many ways this overlapped with her historical writing, in which, to quote Levy, she combined 'attention to the large transformations of public history - above all the ongoing struggle to reform both church and state - and to the small "concrete, personal details" of individual lives'. Her interest in the revelatory power of domestic and private history is evident in her family memoirs too, where she is eager to highlight the ways in which the Aikins' affective relationships connected with, and continued, their political and literary ideals. At the same time, however, she promoted her own larger image of the Aikin family, which could sometimes be at odds with the work of her immediate forebears.

She was the promoter and editor of her father - producing a biography and a selection of his work in 1823 - and, of course, of her aunt Barbauld. Her heavily selective collection of Barbauld's poems and her memoir of her aunt appeared in 1825, with a further selection, $A$ Legacy for Young Ladies, published the following year. Aikin's own 1864 Memoirs - also a family enterprise, produced by her niece and nephew, Anna Letitia and Philip Hemery LeBreton - have also been immensely important in shaping the posthumous reputation of the Aikin family, and in giving rise to other family narratives, including Betsy Rodgers' 1958 Georgian Chronicle: Mrs Barbauld and her family. ${ }^{5}$ Considering these layers of memoirs, collected letters, literary self-reflections and familial observations, Anne Janowitz has spoken of the Aikin family as a 'reputation machine', working away through the nineteenth century and into the twentieth to present a powerful image of exemplary family life. ${ }^{6}$

Except, as that opening image from Aikin's Memoirs shows, this family journey is not always straightforward; the legacies of Dissent can be complex and not always welcome. In this chapter, I want to focus on two interrelated aspects of Aikin's writing life and her 
treatment of her Dissenting inheritance; firstly, her negotiations with her femininity and her role as a female reader and writer, which I want to explore with especial reference to her early poem, Epistles on Women, and, secondly, her presentation of her father and aunt as writers in her biographies, shaped by her double identity as female writer and heir to Barbauld and also by her sense of herself as her father's child. These latter aspects of the essay take their cue from recent revaluations of Aikin's role as biographer and writer, in particular from Janowitz's exploration of the way in which her memoir writing 'interestingly reveals and conceals her own ambivalence about her father's and her aunt's literary vocations'. ${ }^{7}$ Lucy, I argue, seeks to present a particular narrative of the Aikin family which to some extent resists Barbauld's achievements as a woman writer, placing them instead in a context of family creativity, and of her brother's encouragement.

\section{I: Family traditions}

Lucy was born on 6 November 1781, youngest child of John Aikin and Martha Jennings, and heir to a long family tradition of Dissent. She could claim descent from an illustrious line of preachers and educators, since both her father and grandfather, distinguished in their own right, had married into the Jennings family; moreover, she herself was born at Warrington, into one of the centres of provincial Dissent and scholarship. Although she was too young to remember Warrington Academy directly, its intellectual atmosphere was imparted to her both through family friends such as John Howard and Joseph Priestley - Aikin never forgot Howard's kindness to her at eight years old, and his 'interesting conversation with us children', nor the 'cheerful, even playful' Priestley - and through vigorous family attention to her mental development. ${ }^{8}$ From earliest childhood, she was educated within the family, where, after that inauspicious beginning with her grandmother, she had a happier experience being instructed by her father, who taught her natural history when she accompanied him on 
his drives out to see his patients. Her literary and religious sensibilities were nurtured by early reading of her aunt's Lessons for Children, with what she later recalled as their 'spirit of poetry', and Hymns in Prose, which had a strong and lasting effect:

the hymns gave me the idea of something bright and glorious, hung on high above my present reach, but not above my aspirations. They gave me first the sentiment of sublimity, and of the Author of all that is sublime. They taught me piety. ${ }^{9}$

As William McCarthy has already discussed in this volume, this was no uncommon sentiment for nineteenth-century child readers; again, a parallel might be suggested with Harriet Martineau's memories of the Hymns, 'there were parts of them which I dearly loved:' she recalls in her Autobiography, 'but other parts made me shiver with awe'. ${ }^{10}$ The effect was particularly acute for Lucy Aikin, however, as the only next-generation female, with writing ambitions of her own to boot. As my opening anecdote testifies, comparison with Barbauld was a constant feature of Lucy's development, further demonstrated by another story in the Memoirs, a quotation from a letter by John Aikin junior reporting on the precocity of the infant Lucy:

We were talking of Cadmus, and I was saying I was not certain whether he lived before or after the Trojan war; when this chit of six years old decided the matter, by observing that she had heard her brother Edmund read in Pope's 'Homer' about a son of Cadmus fighting against the Trojans. ${ }^{11}$

Not only does this give a powerful image of the sort of shared family reading that characterised the Aikin home, it also demonstrates the pervasive influence of Barbauld's biography on that of her niece, since the story is a retelling of Barbauld's own childhood intervention in her father's theological discussion, as discussed by McCarthy. Lucy Aikin is 
being schooled in a particular tradition of debate and exchange, where even the youngest members of the household are allowed a voice. In her biography of her father, for instance, Lucy Aikin records his habit of having family members read aloud his own work to him, when he 'not only permitted, but invited and encouraged, the freest strictures even from the youngest and most unskilful of those whom he was pleased to call his household critics'. ${ }^{12}$ On the other hand, anecdotes like this show that there were powerful expectations about how and what Lucy Aikin would achieve, her intellectual growth taking shape within the constraints of a larger family narrative. Similarly, Aikin remembers a turning point where she became aware of her own abilities - an early altercation with her brother George about a stolen piece of tart. Running to her parents to remonstrate about the injustice, Aikin was dismissed by her mother:

But how many fold was I compensated when my father, who had listened with great attention to my harangue, exclaimed, 'Why Lucy, you are quite eloquent!' O! neverto-be-forgotten praise! Had I been a boy, it might have made me an orator; as it was, it incited me to exert to the utmost, by tongue and by pen, all the power of words I possessed or could ever acquire-I had learned where my strength lay. ${ }^{13}$

These childhood anecdotes are worth dwelling on since they give a powerful image of the ways in which Aikin's abilities were shaped within a family context, and bound up with her desire for parental approval. Later, she would record her 'proud delight' in having been educated solely within the family: 'my father taught me this, my mother that - one of my brothers informed me of such a thing - in short, not only the foundation-stone, but every other in the fabric of my mind and manners was laid by an honoured and a loving hand - no mercenary touched it!'. ${ }^{14}$ 
This effusion comes in the context of 'a practical lesson in the art of custard-making': family education, for Lucy Aikin, was also deeply connected with domesticity. When discussing her later literary activities, she often takes pains to emphasise their place within her domestic achievements. The comment mentioned by Stephen Daniels and Paul Elliott, for instance, about Aikin helping her father with his geographical writing, records a moment of family collaboration firmly embedded in a domestic setting: 'The Geography is all printed but the index, which my father has made and pasted, with my help. I have weighed out all the bullace and sugar for preserving with my own hands'. ${ }^{15}$ The pairing of the two activities is no coincidence: she is demonstrating her ability to move between two roles, 'her own hands' taking charge both of household chores and intellectual work. 'As literary characters must now and then descend from their altitudes,' she tells Susannah Taylor in 1805, 'I have been several days hard at work upon parlour curtains, which are at length hung up, to the great glory and satisfaction of my mother and me'. ${ }^{16}$ Elsewhere she offers numerous portraits of family life which combine domestic and literary production: her portrait of her father's 'household critics', for example, or her image of her later life in Stoke Newington in a letter which describes her father writing biography, her mother and brother Arthur gardening, and herself stepping 'to the butcher's to order dinner' before settling down to write; in the evenings 'after tea we walk or sit down to our business till candle-light, when we meet with books, and work in the study; after supper we play whist for some time, I read Virgil to my father, and at eleven we march off to bed' ${ }^{17}$

Yet even in the homely account offered by the Memoirs there are hints at the ways in which families might also exert a destructive power. Interspersed with the accounts of John Howard in the Memoirs are reports of his son's insanity and his paranoid fear of being poisoned at family tea parties; lurking behind the Aikin family anecdotes there is the memory 
of the attacks of mental illness experienced by Barbauld's husband Rochemont. In the grip of compulsion and violent delusions, he attacked her several times, on one occasion attempting to force her to drink laudanum, a situation from which she only escaped by throwing herself out of a window; as his aggression increased, the couple were forced to separate, and he committed suicide by throwing himself into the New River in 1808. Rochemont's illness is discreetly veiled in Lucy Aikin's memoir of her aunt, where he becomes 'a sufferer from the most melancholy of human maladies' ${ }^{18}$ Her own opinion of Rochemont, however, was far less sympathetic, as revealed by the multiple revisions of her manuscript, recorded by McCarthy in his biography of Barbauld. Her attraction to Rochemont Lucy Aikin dismisses as 'the illusion of a romantic fancy, not of a tender heart', the result of the 'baleful influence' of too much Rousseau. Had Anna Letitia Barbauld been more affectionate, Lucy continues or rather, she qualifies, had her affections 'been $\wedge^{\wedge}$ arly^ ${ }^{\wedge}$ called forth by a more genial homeatmosphere, she could never have $<$ given $>\wedge$ allowed ${ }^{\wedge}$ herself $<$ up to the insane rhapsodies of constitutional insanity'. 'This is Lucy Aikin,' McCarthy comments, 'nearly inarticulate with fury in her autograph "Family History", writing and crossing out and rewriting'. ${ }^{19}$ She is writing too, as McCarthy points out, from a position of hindsight, informed by her father's perspective, well aware of the ways in which Anna Letitia had rebelled against the wishes of her parents in choosing Rochemont, and feeling anger towards her aunt's irresponsible sentiments of romance. Beneath the surface of family life, there might be dangerous currents of rebellion, violence, and anger; Lucy Aikin's work, as we will see, registers some ways in which this might be contained and closed down.

\section{II: Literary career}

Lucy Aikin began her literary career firstly in 1801 with an anthology of Poetry for Children, published by Joseph Johnson, and then in her own voice in 1810 with a quarto volume, 
Epistles on Women, exemplifying their character and condition in various ages and nations. The Epistles on Women were also published by Joseph Johnson, and printed by Richard Taylor; they carried a dedication to Mrs. Charles Rochemont Aikin. Everything about those details points back to family connection, and the way in which the work is embedded in the religious, intellectual and affectionate culture of the Aikin circle. The choice of publisher was an obvious one: Johnson was deeply committed to the Dissenting cause, financially, politically and socially. ${ }^{20}$ In 1774 , he had helped Theophilus Lindsey establish the Essex Street Chapel, and in the turbulent 1790s he had endured imprisonment as a 'malicious, seditious, and ill-disposed person' for selling Gilbert Wakefield's A Reply to Some Parts of the Bishop of Llandaff's Address. ${ }^{21}$ Throughout the decades, his house and shop had functioned as a hub of a Unitarian intellectual network which stretched across the country, from Warrington to Norwich. Although Joseph Johnson had died the year before Lucy Aikin's book appeared, his two assistants continued to publish under his name, and so her first work was published under the same auspices as that of her father, taking its part in a line of family writings issued by Johnson for over thirty years, signalling its loyalties to the larger family of Unitarian Dissent from its very title page. Even the choice of printer, Richard Taylor, indicates a further connection to Unitarian culture, intellectual and familial. He offers a nice example, too, of the intersections between Dissent, science and industry which Ian Inkster's contribution to this volume highlights. Born into a Norwich family of manufacture and Dissent, Taylor's professional and intellectual interests coincided; he not only printed a wide range of scientific books and periodicals which featured science, including The Monthly Magazine, but was also a fellow of the Linnean society. His firm was also a powerful family institution, since Taylor took his natural son William Francis into the business; indeed, their company, Taylor and Francis, is still one of the leading publishers of scientific journals. As 
we will see, there were also familial and emotional bonds between the writer and the printer of Epistles, since all the Taylors were closely friendly with the Aikin clan. ${ }^{22}$

Simply on a bibliographic level, then, the book is meshed into a larger structure of Dissenting networks. While Lucy Aikin presents the 'Introduction' to her Epistles with 'all the diffidence and anxiety of a literary novice conscious of a bold and arduous undertaking' she has the weight of family tradition and support behind her, and is self-consciously continuing a family literary lineage. The dedication confirms the strength of these connections:

TO Mrs. CHARLES ROCHEMONT AIKIN, THE FOLLOWING EPISTLES, ORIGINALLY ADDRESSED TO HER BY THE SOLE APPELLATION OF FRIEND, ARE NOW INSCRIBED, TOGETHER WITH THE REMAINING CONTENTS OF THIS VOLUME, BY HER AFFECTIONATE FRIEND AND SISTER LUCY AIKIN.

Anne Wakefield, daughter of Gilbert, had married Lucy's brother, Charles, in August 1806. This dedication demonstrates the interlinking of the various Dissenting intellectual clans: Wakefield, who had been appointed as classical tutor at Warrington in 1779, had been close friends with both John Aikins, father and son. The exchange and friendship of the previous generations was confirmed in the intermarriages of the next. Furthermore, Charles, the second son of John Aikin, had been adopted by the Barbaulds at the age of two, although the siblings had remained close, so the dedication also binds Lucy and her aunt's family together. The Dedication of the Epistles also finds a direct parallel in the Barbauld poem, 'Lines for Anne Wakefield on her Wedding to Charles Rochemont Aikin, with a Pair of Chimney Ornaments in the Figures of two Females seated with open Books'. The poem allegorises the two figures as Science and Love, intellectual achievement and family affection which are 
brought together in the marriage. The two poems - Barbauld's short wedding-present tribute, and Lucy Aikin's 1,200 line Epistles - thus occupy a similar place in the family culture of gift-circulation and of women celebrating and confirming one another's achievements.

Lucy Aikin's poem itself is a bold and confident tribute to female power. Four books of heroic couplets recount the history of humanity from the Garden of Eden to 1750, linking the progress of civilisation specifically to women and their achievements. Recent criticism has provided new insights into the feminist strategies of Epistles: poetical, political, and historical, in terms both of Lucy's contribution to feminism and to historiography. Anne Mellor places it as a triumphant culmination at the end of her chapter on women's political poetry in Mothers of the Nation, 'a female-authored poem,' she says, 'which more than any other mounted a demand for a social revolution, for the initiation of a women's movement which would overthrow the existing construction of gender and ensure the equality, perhaps even the social and political superiority, of the female'. ${ }^{23}$ Kathryn Ready, who has examined its use of stadial theory in detail, has discussed the poem as a 'unique contribution to Enlightenment feminist thought', and this idea is supported by Kathryn Gleadle's suggestion that the poem functions as an important intermediary stage 'between the arguments of the Enlightenment anthropologists, and the radical unitarian feminists of the 1830 s and 1840 s' $^{24}$ Without downplaying the significance of Lucy's writing, I want to investigate its possible tensions and conflicts, reading her feminism in light of her familial commitments. Michelle Levy, in the previous chapter, shows how the poem 'claims the right of women to retell their own history', and should be read alongside Lucy's own retellings of history in her series of court Memoirs. ${ }^{25}$ Alongside this exploration of Lucy as innovative historian, I want to read the Epistles in light of her retellings of family history, affording us a slightly different perspective on her writing. 
Epistles begins with an apparent rejection of "the absurd idea that the two sexes ever can be, or ever ought to be, placed in all respects on a footing of equality'. ${ }^{26}$ Instead, Lucy appeals for the recognition of separate spheres of women's achievements and pride in a specifically female identity: 'No! instead of aspiring to be inferior men, let us content ourselves with becoming noble women:... but let not sex be carried into every thing' ${ }^{27}$ Yet this apparently demure preface conceals a subversive element. Having made the claim for two distinct, gendered spheres, Lucy fiercely attacks the ways in which men treat women. '[I]t is impossible for men to degrade his companion without degrading himself', she comments, before opening the poem with a severe indictment of the value placed upon ephemeral female charm: woman is a 'poor helpless passenger from love to scorn', not because of inherent failings but because men do not value female intellect. Lucy outlines the ways in which male constraints have created the attributes of femininity, only to tire of them: once beauty fades, the poem asserts, 'man contemns the trifler he has made'. As the historical narratives begin, the poem goes on to make a claim not simply for the equal intelligence of women, but for their superiority. Certainly that is the case with the portrait of Adam, listless and torpid, with 'fixt infantile stare', until Eve's appearance:

Sure a new soul that moping idiot warms,

Dilates his stature, and his mien informs! $!^{28}$

Eden is presented rather as a state of mind or emotion than a place - 'Eden opened in the heart of Man' - and is defined primarily through equality of the sexes:

Equal they trod till want and guilt arose,

Till savage blood was spilt, and man had foes. ${ }^{29}$

Crucially, 'want and guilt' do not belong solely to the female, and the ambiguous phrasing of 'savage blood' leaves the nature of the savagery unspecified: 'savage' could characterise the 
blood, Adam or Eve, or another force outside their equal realm. In the next epistle, however, depicting a distinctly un-Rousseauvian primitive savage state, women are the victims, not participants, in savage behaviour. Man is shown as a 'reckless hunter', 'of beasts the worst, / in want, in guilt, in lawless rapine nurst'. 30 'Certainly Rousseau did not consult the interests of the weaker sex in his preference of savage life to civilised', Lucy comments dryly in her notes. ${ }^{31}$ From this savage state we move to a pastoral setting, then into scenes from classical epic as Lucy rewrites Homer from the female viewpoint, suggesting a bleak picture of the condition of women in the Greek republic: 'Thy wives, proud Athenians! fettered and debased'. We move gradually forward, through a survey of Hindu widows and Turkish harems, into a discussion of important women through history, and close by looking toward an enlightened future of intellectual equality, as she urges the 'sons of fair Albion' to 'unbind / Your barbarous shackles, loose the female mind'. ${ }^{32}$

The epistles move broadly along the lines of stadial, or four-stage, theory - where man is traced through four broad social stages, hunting and fishing; pasturage; agriculture; and commerce or manufacturing, and where a society's progress can be measured and determined by its treatment of women. Kathryn Ready has powerfully demonstrated Lucy Aikin's debt - and her contribution - to Enlightenment historiography including stadial theory, while pointing out that Aikin's application of this 'to understanding historical and geographical variations in the status of women is never formulaic'. ${ }^{33}$ Stadial theory would later powerfully influence both Jane Marcet, whose Conversations on Political Economy Aikin would read in June 1817, when she tells her brother she is enjoying them in spite of herself, and Harriet Martineau, whose Illustrations of Political Economy explore, as Ella Dzelzainis has analysed, the 'feminist potential of [...] stadial theory' ${ }^{34}$ Lucy's, too, is a feminist version of stadial theory. Savage behaviour is, in her version of history, perpetrated by men, as when her savage 'monster-man' preys on womankind: 
Mark the grim ruffian roll his crafty glance,

And crouching, slow, his tiger-step advance,

With brandisht club surprise his human prey,

And drag the bleeding victim bride away. ${ }^{35}$

This lack of empathy is contrasted with female self-sacrifice in the same epistle,

Maternal Love! thy watchful glances roll

From zone to zone, from pole to distant pole;

Cheer the long patience of the brooding hen,

Soothe the she-fox that trembles in her den,

'Mid Greenland ice-caves warm the female bear,

And rouse the tigress from her sultry lair.

At thy command, what zeal, what ardour, fires

The softer sex! a mightier soul inspires... ${ }^{36}$

Even in a savage state, therefore, female creatures are presented as having superior powers of empathy demonstrable in their behaviour towards their families, pointing the way towards a state of civilisation later in the poem. Aikin's use and interrogation of Enlightenment historiography here reminds us that she is - as Ready, and Levy in her essay for this volume, have shown us - actively reinterpreting women's history, setting her in a larger community of women writers such as Marcet and Martineau. Indeed, in October 1832, Lucy Aikin would read and greatly approve of Martineau's Illustrations. 'Know that a great new light has arisen among English women' she told William Ellery Channing, praising the principles of her political economy stories, and the 'grace', 'animation' and 'powerful pathos' of her narratives. ${ }^{37}$ Lucy Aikin's own project, '[t]o mark the effect of various codes, institutions, 
and states of manners, on the virtue and happiness of man, and the concomitant and proportional elevation or depression of woman in the scale of existence' (Epistles, vii) therefore takes its place in a larger feminist appropriation of male narratives of history.

Yet Lucy's feminism picks its way carefully between family loyalties and feminine ideals. Recent work on Aikin has repeatedly returned to the implications of her treatment of femininity, maternity and domesticity. Anne Mellor discusses the way in which Aikin 'praises those women who carried the values of maternal love into the public realm', concluding that she closes Epistles by affirming 'the domestic affections as the noblest model for all public and private social relationships'. ${ }^{38}$ Harriet Guest, meanwhile, reads a greater ambivalence into Aikin's emphasis on domesticity, uncovering its political charge by analysing her portrayal of Spartan women in particular detail: for Aikin, she argues, domesticity becomes 'the site from which an oppositional political discourse can be articulated'. ${ }^{39}$ Kathryn Ready, returning to these arguments through a nuanced reading of the poem's use of stadial theory, has suggested that we see Aikin as striving to 'reconcile the republican and commercial models of femininity to promote women's education' ${ }^{40}$ All these approaches return to the ways in which Aikin expresses interest in some forms of dominant behaviour by women while simultaneously displaying a repeated distrust of women whose power is achieved or deployed in aggressive or 'relentless' ways, such as Queen Bondica, or 'the dread Eliza', Elizabeth I. Instead, she reserves her highest praise for those women whose behaviour in the public realm is informed by their values of family love and devotion, such as Margaret Roper, pictured weeping, 'pale and shrieking', at the execution of her father Thomas More. This act of filial piety finds its own textual echo in the footnotes, which give an account of Roper's 'reverence and affection for her father' drawn directly from John Aikin's General Biography. ${ }^{41}$ Both through her narrative of Roper and through her own practice, Lucy Aikin suggests that women's claim to immortality rests upon their relationship 
to the family, in filial or maternal affection. This, I argue, should be seen as a model for understanding her practice both as a writer and as a family biographer; women's achievements and ambitions, while they may be celebrated, must also be understood in relation to their familial role, an idea which gains special force in the context of Aikin family ideology. Ultimately it is the family which gives the woman strength, and which, perhaps, has more force than the woman herself.

We might look back to the ways in which Lucy herself had been educated, and her repeated placement of her literary work within a larger context of familial pride and domesticity. Her correspondence with female friends continues this pattern: for example, the letters she sent in the early 1800s to the family friend Susanna Taylor, mother of Richard Taylor, who would later print the Epistles. These letters, composed when she was already writing the Epistles, give interesting insights into the creation of this powerful family-centred ideology. For a start, they represent not only a friendly exchange of letters, but the intersection of two major Dissenting family networks, which perhaps accounts for the slightly self-conscious tone adopted by Lucy. Susanna (1755-1823) was her mother's generation, wife of John Taylor, Unitarian hymn-writer and yarn manufacturer, the grandson of John Taylor the Presbyterian divine. The Taylor clan provide a parallel with the Aikins. Related to or friendly with a wide range of other Dissenters - the Martineaus, the Opies, William Enfield, Henry Crabb Robinson, they and their descendants populate all sorts of branches of learning and intellectual exploration. Of Susanna's children, John Taylor (1779-1863) was a mining engineer, Edward Taylor (1784-1863) became Gresham professor of music, and Philip Taylor (1786-1870) was a civil engineer; Richard, printer and naturalist, was joined by his brother Arthur in the firm. Susanna's daughters Susan and Sarah were also highly educated: Sarah (1793-1867), under her married name of Austin, was to achieve fame as a translator from the German, and Susan (1788-1853) was later to marry Henry Reeve (1780- 
1814), a renowned physician, student under Philip Martineau, who was the uncle of Harriet. Susan's son, Henry Reeve junior, was a translator, leader-writer of the Times, and, eventually, editor of the Edinburgh Review. As with the Aikin family, there is a powerful sense of an interconnected, intergenerational nexus of exchange between industry, exploration, European culture and journalism.

Lucy Aikin's letters to Taylor reveal a remarkable range of reading, placed within a circle of familial or friendly exchange, as in her discussion, in January 1803, of a 'lady's book society' she has set up with Barbauld. The feminism of this enterprise, however, is immediately qualified; even as Aikin asks Taylor to admire 'our spirit in setting up an institution into which not a single man is admitted, even to keep the accounts', she goes on to stress the essential femininity of the assembled women:

I must indeed whisper in your ear that it is no very easy matter to get the ladies to suspend their dissertations on new plays and new fashions to discuss the merits of books, and that sometimes it is rather difficult for the president, treasurer, and secretary, calling all at once to order, to obtain a hearing. ${ }^{, 42}$

This sense of careful negotiation between feminism and femininity appears too in her comments in the same letter on a 'singular work lately published': Mary Hays' six-volume Female Biography or, Memoirs of Illustrious and Celebrated Women of All Ages and Countries (1802). This remarkable work is now - like Lucy Aikin's historical writing slowly being recognised as groundbreaking. Mary Spongberg terms it 'the first and perhaps the most important collection of women's lives': it is a lively, critical, wide-ranging rewriting of biography from a female perspective. ${ }^{43}$ As such, it would seem to be a natural forebear for Aikin's own work. However, Aikin distances herself from Hays, whom she describes as a 'great disciple of Mrs Godwin'. As such she might well have been expected to interest a 
woman like Susanna Taylor, who is said to have danced round the tree of liberty in Norwich at the news of the fall of the Bastille. Certainly Susanna's husband's hymn, 'Trumpet of Liberty', was composed for the occasion, and sung at a public celebratory Revolutionary dinner on the $5^{\text {th }}$ November, 1789. But despite these connections, and despite the similarity of their female-centred projects, Aikin distrusts Hays' 'zealous' feminism. Quoting Swift, she tells Susanna Taylor that 'Her arguments directly tend /Against the cause she would defend. [...] Alas, alas! though Miss Hayes has wisely addressed herself to the ladies alone, I am afraid the gentlemen will get a peep at her book and repeat with tenfold energy that women have no business with anything but nursing children and mending stockings.' This gets to the nub of Aikin's problem with Hays: her feminism is too overt. Aikin's comments here anticipate Barbauld's better-known assertion to Maria Edgeworth in 1803 that 'there is no bond of union among literary women [...] Mrs. Hannah More would not write along with you or me, and we should probably hesitate at joining Miss Hays, or if she were living, Mrs Godwin'. ${ }^{44}$ One reason for this hesitation is given by Lucy Aikin to Susanna Taylor: 'I do not think her book is written quite in an edifying manner neither - the morals are too French for my taste.' In Female Biography, the pious and the rebellious are placed side by side: close on the heels of Margaret Roper, for example (whose learning and intellect are praised as highly as her family piety), comes Madame Roland, to whom a large proportion of Hays' sixth volume is dedicated: 'heroine of the French revolution, and the martyr of liberty'. ${ }^{45}$ While both authors exhibit interest in the ways in which women shape their history and historiography, Hays is drawn to defiant and independent characters. Aikin, on the other hand, treats 'the Character of Women' as a subject 'which is delicate and requires management', in Barbauld's words. ${ }^{46}$ And while Aikin's book-club is composed of ladies, female writing which, like Hays's, remains spiky, rebellious, unrepentant, is still viewed with suspicion. 
Meanwhile Aikin herself was negotiating similar problems as a writer, as revealed in a subsequent letter to Susanna Taylor. ${ }^{47}$ She describes her slow progress writing the epic (this is 1805 , so it would go on for some time yet): 'On the whole, I consider the Roman dames as the queens of their sex, but there are a few ugly facts against them which I do not well know what to do with. At one time they had a disagreeable habit of poisoning their husbands; but I don't think much of that,' she adds saucily, 'for no doubt the men gave them provocation.' This leads her off into a story about a 'heroine' of Newington Green, a cook maid who stabbed the footman in a dispute; a story she implicitly parallels to the 'wild and lawless manners of the old Scotch Borderers', the 'valiant marauders' who seize her imagination when reading Walter Scott. It is perhaps significant that almost immediately after describing this imaginative violence, this rebellious, lawless characters - and an episode which brings them into the heart of domesticity - she moves into a spot of sentimental moralising about family and home. Setting herself up - however playfully - as more prudent than Barbauld, 'who is at least forty years younger than I am' and given to gaiety and racketing, she rather cloyingly muses on her 'homebred satisfactions': her dedication to home and its 'revered inhabitants', exclaiming 'Oh! How could I ever bear to be separated from those who unite in themselves all the strongest titles to my gratitude and affection'. ${ }^{48}$ Lucy Aikin's rhetorical appeal to the family is backed up by references to Taylor's domestic 'fireside circle', and an appeal to her daughter Susan to write. Potentially subversive, violent behaviour - from the Roman matrons, the cook's maid, or from reading Scott's lawless adventurers - is evoked, and then firmly closed down into the safety of family sentiment.

Like the Epistles, Aikin's letters to Taylor show a certain tension in negotiating the claims of family and feminism: both argue that a woman's power, social and literary, must be carefully negotiated and claimed through the family rather than as an individual. I want now 
to turn back to the concluding passages of Epistles to see this in action. Here, Lucy Aikin addresses a land of enlightened women readers, 'bright daughters of a land renowned', and looks forward to a time of equality between man and woman. But she is also addressing one particular daughter, the dedicatee Anne Wakefield. This national appeal is elided with the personal, since this evocation of future social and intellectual equality is also a portrait of Anne's future marriage:

'Tis yours to elevate, 'tis yours to bless;

Your interest one with his; your hopes the same. ${ }^{49}$

These lines look back to Barbauld's poem 'The Rights of Woman' - often seen as an angry answer to Mary Wollstonecraft's Vindication of the Rights of Woman - and its closing call for 'separate rights [...] lost in mutual love'. Barbauld's is a difficult poem to read, particularly in relation to Wollstonecraft, since it carries a charge of knowing, sexually alert irony. ${ }^{50}$ The possibility of irony, however, is lost in these closing stanzas of her niece's poem. Instead, the wider social ideal thus becomes identified with one particular inter-family marriage, so that the Aikin family is seen as the ultimate model for reform. The final verse of the poem gives us an image of 'Anna', Anne Wakefield, as intellectually and affectionately nourished within her family; her learning indistinguishably linked to fatherly love:

(For not the Roman, not the Attic store,

Nor poets' song, nor reverend sages' lore

To thee a Wakefield's liberal love denied,

His child and friend, his pupil and his pride). ${ }^{51}$

That image of learning and love coming together comes very close to Barbauld's poem, 'Lines for Anne Wakefield on her Wedding [...] with a Pair of Chimney Ornaments in the Figures of two Females seated with open Books'. The ornaments, Anne's daughter recalled, 
were 'two beautiful little female figures [in Wedgwood ware] seated on cushions, each with an open book on her knees, and in one hand a gilt flower cup to hold a candle'. ${ }^{52}$ Here, one figure represents science, in imagery very close to Aikin's poem:

The stores of Rome and Greece I spoil,

And feed my lamp with Attic oil;

While for my mistress I explore

The treasures deep of ancient lore.

The matching figure represents love, a feminine ideal identified by 'gentle deeds and rosy smiles', and thus allows an interpretation of the poem along gendered lines, with Charles representing science and Anne love. Certainly this was the way in which Anne's daughter would read it, recording in her Memories of Seventy Years, where the poem was first published, that: 'My father's lamp of Science burned long, my poor mother's lamp of Love was soon extinguished by the hand of Death'. ${ }^{53}$ Yet Barbauld's poem in some ways resists that gendered reading. After all, the poem is addressed solely to Anne, and both the figures are female readers, sisters; the representation of science clearly tells us she is gathering material 'for my mistress'. Marriage will unite science and love in Anne's own mind, perhaps - so that one figure might represent Anne Wakefield, and the other Mrs Charles Rochemont Aikin, before and after marriage. And this might also be where Barbauld's poem differs from that of Lucy Aikin. In the Epistles, Anne's wedding becomes symbolic of a much larger social ideal, read as part of the family and part of a historical narrative of progress. Barbauld's small poem, circulated in manuscript, is a more private enterprise, and also, I think, remains slightly evasive: it is both about the marriage and about Anne's growth as an individual. Subsequent family readings, by Lucy Aikin and by Anna Letitia LeBreton, have turned it into a family narrative, rather than a female one. 


\section{III: Biographies}

In my closing section, I want to move to perhaps the most obvious example of this sanitisation in Lucy Aikin's biographies of Barbauld and her father, and to show how these are structured and to some extent constrained by the familial model. On the one hand, both biographies, especially that of her father, convey a strong sense of literary sociability and family creativity, and contain wonderful descriptions of friendly and domestic reading. Lucy Aikin reports, for instance, on her father's 'social and communicative habits of study' ${ }^{54} \mathrm{He}$ often discussed his reading with the family; similarly, one of his writing habits was 'never to commit a single page to the printer without causing it to be previously read aloud by one of his family in his own presence, and in that of any other members of the domestic circle who could be conveniently assembled'. ${ }^{55}$ The Aikin family is set up as a democratic powerhouse, with all invited to contribute. However, this also has the effect of absorbing individual voices, transforming them into part of a larger family narrative. I think this becomes a motivating factor in Lucy Aikin's representation of Barbauld in the memoir attached to her 1825 edition of her Works: a representation of her as feminized, conservative, ripe for Victorian appropriation. A representation, moreover, which would subsequently lead, as the critical tide turned against this Angel in the House, to her being reinterpreted as starchy, solemn, priggish and Whiggish. Aikin's portrayal of Barbauld as possessing 'a double portion of bashfulness and maidenly reserve', and her emphasis on her aunt's bloom, her beauty and her dark blue eyes certainly contribute to this effect. ${ }^{56}$ More damaging still, as McCarthy has shown, is her partial, biased and deliberately misleading account of her reluctance to establish an academy for young ladies. Aikin reports her aunt's rejection of this plan in the Memoirs as 'a monument of her acuteness and good sense', or, in other words, her anti-feminism. ${ }^{57}$ Replacing the letter in its proper context and redirecting it to its proper recipient, Rochemont 
Barbauld, William McCarthy has given a different interpretation of Barbauld's rejection of the plan for a female academy. The crux of the matter, in his re-reading of the letter, is not Barbauld's modesty, but her defence of her identity and her time as an author: taking on a head-mistress-ship would have dangerously encroached on her writing career. The feminized, unfeminist Barbauld thus presented by Aikin, who steers her well out of the choppy Jacobin waters of the 1790s into the calmer reaches of children's education, is a misrepresentation drawn from Aikin's anxiety about the ways in which her aunt had been vilified by the Quarterly Review: a 'surely honorable and protective' impulse, writes McCarthy. ${ }^{58}$ This is true, and there is certainly a benign aspect to this rewriting, despite, as he points out, its effect on the later reputation of Barbauld, noting the irony 'in Lucy Aikin's having done for (or to) Barbauld textually what Barbauld herself felt had not been successfully performed upon her in life: rendering her conventionally feminine. And there is more than irony, there is something like historical tragedy, that in protecting Barbauld from attack by enemies who did not, in fact, attack her, Lucy Aikin laid her open, in the longer run, to attack by those who should - and, if properly informed, surely would - have been her friends.' 59

In closing I want to suggest a further aspect of Aikin's negotiation with her aunt's legacy: not only that she wants to bring a more feminised Barbauld into step with post-1790s politics, but also, interconnectedly, that she is making an important claim for an alternative Aikin legacy, seeking to displace Barbauld from the forefront of their intellectual narrative, and emphasise her status as merely part of a larger family story. It is the same ideology which lies behind the Epistles - female power, female action, celebrated not as the achievement of an individual, but within the family context. The effect of Aikin's censored letter, for instance, is both to emphasise Barbauld's feminine distrust of feminist undertakings, and also to show her as a product of the Aikin family, rather than as an individual, self-determining 
author. She also persistently shows her aunt as having to be encouraged and dragged from her torpor into literary production: she 'could seldom excite herself to the labour of composition,' Aikin tells us, 'except on the spur of occasion', and presents her as having been constantly prompted by her brother. In Aikin's biography of John Aikin, Barbauld first appears as his 'beloved confident', not as an author in her own right, but lovingly encouraging the authorial ambitions of her brother. It is only well into the first chapter that her own writing is mentioned, and then it comes firmly under the auspices of her brother, as Aikin depicts her prompted into poetry by John Aikin's 1772 Essays on Song Writing, and then encouraged into print by him:

He had the high gratification of aiding his sister in selecting, revising, and conducting through the press, her volume of poems, which the urgency of his entreaties had chiefly prevailed upon her to give to the world; - their success proved equal to their merit; and while it justified the judgment of her brother from the imputation of partiality, it swelled his heart with the purest emotions of delight and triumph. ${ }^{60}$

This is expanded in Aikin's Memoirs of Barbauld:

By his [John Aikin's] persuasion and assistance, her Poems were selected, revised, and arranged for publication: and when all these preparations were completed, finding she still hesitated and lingered, - like the parent bird who pushes off its young to their first flight, he procured the paper, and set the press to work on his own authority. ${ }^{61}$

This is more than encouragement; more, even, than 'urgent entreaty'. This is Aikin bringing the poems into the world, 'like the parent bird'. He might not, indeed, be the author, but they are produced 'on his own authority'. This pattern is repeated when it comes to the appearance of their joint volume, Miscellaneous Pieces in Prose. While she admits in her biography of 
her father that 'the share of Mr. Aikin in this collection was considerably the smallest and least important', she also wishes it to be known that his essay on the heroic poem of Gondibert 'produced a considerable effect, and has been many times republished by the compilers of selections'. ${ }^{62}$ But by the time this passage reaches the biography of her aunt, however, it has been expanded to underscore John Aikin's role as motivator and prime mover in the family's literary inheritance:

her brother, who possessed all the activity and spirit of literary enterprise in which she was deficient, now urged her to collect her Prose Pieces, and to join him in forming a small volume. ${ }^{63}$

This, I think, goes further than wanting to reclaim Barbauld as feminine, bashful and modest: it also seeks to make a larger claim for the authority, and the authorial power, of John Aikin, and, in a wider sense, the Aikin family. As in the Epistles, women's power is shown as most effectively taking shape through their family relationships. Daniel White has spoken about the ways in which middle-class Dissenting women writers could strategically use 'their dual status as private family members and professional authors to enter public discourse from a tenuous but potentially privileged station': writing within the family model, he suggests, allows both protection and freedom for Barbauld, an intimate sphere which is also connected to a wider political and social world. ${ }^{64}$ In Lucy Aikin's reading, it can also become a constraint, looking not outward to the wider world, but pointing conservatively inward, so that Barbauld's subversive voice is enclosed, and almost smothered, by her role as sister, mother, beloved children's teacher. We began with an image of the child's resentment at being compared to her precocious aunt and elder brother; this is, perhaps, her belated attempt to re-adjust the formidable Aikin family narrative. 
Notes

${ }^{1}$ Philip Hemery Le Breton (ed.), Memoirs, Miscellanies and Letters of the Late Lucy Aikin (London: Longman, 1864), x.

${ }^{2}$ Le Breton, Memoirs, xi.

${ }^{3}$ Michelle Levy, Family Authorship and Romantic Print Culture (Basingstoke: Palgrave, 2008), 21. See also Daniel E. White, Early Romanticism and Religious Dissent (Cambridge University Press, 2006), particularly chapter 3, 66-86.

${ }^{4}$ Harriet Martineau, Autobiography, ed. Linda H. Peterson (Peterborough, ON: Broadview, 2007), 126.

${ }^{5}$ Betsy Rodgers (née Aikin-Sneath) (1907-1998) was a descendant of John Aikin, an academic and historian who first specialised in German drama before writing her books on charity in the eighteenth century and on Barbauld. See obituary by Susan Lasdun, Independent (5 June 1998).

${ }^{6}$ Anne Janowitz, 'Memoirs of a Dutiful Niece: Lucy Aikin and literary reputation', in Heather Glen and Paul Hamilton (eds.), Repossessing the Romantic Past (Cambridge University Press, 2006), 80. 
${ }^{7}$ Ibid. 93.

${ }^{8}$ Le Breton, Memoirs, xii.

${ }^{9}$ Ibid., xviii.

${ }^{10}$ Martineau, Autobiography, 55.

${ }^{11}$ Le Breton, Memoirs, xiii.

${ }^{12}$ Lucy Aikin, Memoir of John Aikin, M.D. with a Selection of Miscellaneous Pieces,

Biographical, Moral and Critical, 2 vols. (London: Baldwin, Cradock and Joy, 1823), 200.

${ }^{13}$ Le Breton, Memoirs, xvii.

${ }^{14}$ Ibid., 87.

${ }^{15}$ Ibid., 82.

${ }^{16}$ Ibid., 133. Lucy's pride in her achievement might be set alongside Martineau's loaded comment that Barbauld 'was not much of a needlewoman' ('What Women are Educated For', Once a Week (10 August, 1861), 177), discussed in my 'Introduction'. 
${ }^{17}$ Ibid., xxiv.

${ }^{18}$ Ibid., xliv.

${ }^{19}$ William McCarthy, Anna Letitia Barbauld: Voice of the Enlightenment (Baltimore: The Johns Hopkins University Press, 2008), 135.

${ }^{20}$ See Helen Braithwaite, Romanticism, Publishing and Dissent: Joseph Johnson and the Cause of Liberty (Basingstoke: Palgrave, 2003).

${ }^{21}$ See Gerald P. Tyson, Joseph Johnson: A Liberal Publisher (Iowa City: University of Iowa Press, 1979), 159-61.

${ }^{22}$ W. H. Brock and A. J. Meadows, The Lamp of Learning: Two Centuries of Publishing at Taylor \& Francis (London and Bristol, PA: Taylor and Francis Ltd., 1998). See also Jonathan R. Topham, 'Technicians of print and the making of natural knowledge', Studies in History and Philosophy of Science, 35:2 (2004): 391-400.

${ }^{23}$ Anne K. Mellor, Mothers of the nation: women's political writing in England, 1780-1830 (Bloomington, Indiana: Indiana University Press, 2000), 80.

${ }^{24}$ Kathryn Ready, ‘The Enlightenment Feminist Project of Lucy Aikin's Epistles on Women (1810)', History of European Ideas 31 (2005): 435-450 (449); Kathryn Gleadle, The Early 
Feminists: Radical Unitarians and the Emergence of the Women's Rights Movement, 1831-5 (New York: St. Martin's Press, 1995), 68.

${ }^{25}$ While the merit of Aikin's poetry is still a subject for debate - see Anne Janowitz, 'The Aikin Family, Retrospectively', supra - a new edition of her poetry and prose by Mellor and Levy, Epistles on Women and Other Works, points the way towards an increased appreciation of the historical and literary significance of Lucy Aikin's work.

${ }^{26}$ Epistles on Women, exemplifying their character and condition in various ages and nations. With Miscellaneous Poems. By Lucy Aikin (London: Johnson, 1810), v.

${ }^{27}$ Ibid., vi.

${ }^{28}$ Ibid., 10.

${ }^{29}$ Ibid., 12.

${ }^{30}$ Ibid., 18.

${ }^{31}$ Ibid., 84 .

${ }^{32}$ Ibid., 78. 
${ }^{33}$ Kathryn Ready, 'The Enlightenment Feminist Project of Lucy Aikin's Epistles on Women (1810)', 440.

${ }^{34}$ Ella Dzelzainis, 'Reason vs Revelation: Feminism, Malthus, and the New Poor Law in Narratives by Harriet Martineau and Charlotte Elizabeth Tonna', 19: Interdisciplinary Studies in the Long Nineteenth Century, 2 (2006), 4.

${ }^{35}$ Epistles, 17.

${ }^{36}$ Ibid., 22.

${ }^{37}$ To Dr. Channing, 15 Oct. 1832, Correspondence of William Ellery Channing D.D., and Lucy Aikin (London and Edinburgh: Williams and Norgate, 1874), 148.

${ }^{38}$ Anne K. Mellor, 'The Female Poet and the Poetess: Two Traditions of British Women's Poetry, 1780-1830', Studies in Romanticism, 36 (1997): 261-276 (275; 276).

${ }^{39}$ Harriet Guest, Small change: women, learning, patriotism, 1750-1810 (University of Chicago Press, 2000), 18; 335-338.

${ }^{40}$ Kathryn Ready, 'The Enlightenment Feminist Project of Lucy Aikin's Epistles on Women (1810)', 449. 
${ }^{41}$ John Aikin, General biography; or lives, critical and historical, of the most eminent persons of all ages, countries, conditions, and professions, 10 vols. (London, 1799-1815), 7: 208.

${ }^{42}$ Lucy Aikin, letter to Susanna Taylor, January 27 1803, Le Breton, Memoirs, 124-7.

${ }^{43}$ Mary Spongberg, Writing Women's History since the Renaissance (Basingstoke: Palgrave Macmillan, 2002), 115-118.

${ }^{44}$ Barbauld, letter to Maria Edgeworth, August 1804, in Anna Letitia Le Breton, Memoir of Mrs. Barbauld, Including Letters and Notices of Her Family and Friends (London: George Bell and sons, 1874), 84 .

${ }^{45}$ Mary Hays, Female Biography, or Memoirs of Illustrious and Celebrated Women, of all Ages and Countries Alphabetically Arranged, 6 vols. (London: Richard Phillips, 1803), 6: 103. Hays has been criticised for her exclusion of Mary Wollstonecraft, and Female Biography seen as a departure from her earlier radicalism; I follow Gina Luria Walker, however, in seeing the work as a continuation and extension of Hays' feminist convictions (see Gina Luria Walker, Mary Hays (1759-1843). The Growth of a Woman's Mind (Aldershot: Ashgate, 2006), particularly 222-229).

${ }^{46}$ Barbauld, letter to Lydia Withering, cited by McCarthy, Anna Letitia Barbauld: Voice of the Enlightenment, 500. 
${ }^{47}$ Lucy Aikin, letter to Susanna Taylor, March 23 1805, in Le Breton, Memoirs, 127-30.

${ }^{48}$ Ibid., 128-9.

${ }^{49}$ Epistles, 80.

50 'The Rights of Woman', Barbauld, Selected Poetry and Prose, 130-1 (see also the headnote by the editors exploring the ironic potential of the poem).

${ }^{51}$ Epistles, 81.

${ }^{52}$ Anna Letitia LeBreton, Memories of Seventy Years by one of a literary family, ed. Mrs Herbert Martin (London: Griffith \& Farran, 1883), quoted in Barbauld, Selected Poetry and Prose, 150-1.

${ }^{53}$ Memories of Seventy Years, 62; Barbauld, Selected Poetry and Prose, 151.

${ }^{54}$ Lucy Aikin, Memoir of John Aikin, I: 201.

${ }^{55}$ Ibid., I: 200.

${ }^{56}$ Lucy Aikin, The works of Anna Latitia Barbauld: With a memoir, 2 vols. (London: Longman, Hurst, Rees, Orme, Brown, and Green, 1825), I: x. 
${ }^{57}$ Ibid., xvi.

${ }^{58}$ William McCarthy, 'Why Anna Letitia Barbauld Refused to Head a Women's College:

New Facts, New Story', Nineteenth-Century Contexts, 23:3 (2001): 349-79 (365).

${ }^{59}$ Ibid.

${ }^{60}$ Lucy Aikin, Memoir of John Aikin MD, I: 20.

${ }^{61}$ Lucy Aikin, The works of Anna Latitia Barbauld: With a memoir, I: xii.

${ }^{62}$ Lucy Aikin, Memoir of John Aikin MD, I: 21.

${ }^{63}$ Lucy Aikin, The works of Anna Latitia Barbauld: With a memoir, I: xiii.

${ }^{64}$ Daniel E. White, Early Romanticism and Religious Dissent (Cambridge University Press, 2006), 68 . 